\title{
Assessing the Problem of Human Capital Mismatch in Transition Economies
}

\author{
By: Viliam Druska, Byeong ju Jeong, Michal Kejak, \\ and Viatcheslav Vinogradov
}

William Davidson Working Paper Number 467

March 2002 


\title{
ASSESSING THE PROBLEM OF HUMAN CAPITAL MISMATCH IN TRANSITION ECONOMIES
}

\author{
Viliam Druska, Byeongju Jeong*, Michal Kejak, and Viatcheslav Vinogradov \\ CERGE-EI \\ POB 882, Politickych veznu 7 \\ 11121 Prague 1 \\ Czech Republic \\ tel: $420-2-24005258$ \\ fax: $420-2-24211374$ \\ email: byeongju.jeong@cerge-ei.cz
}

March 2002

* Corresponding author. The research for this paper was supported by the grant European Union Phare ACE P97-8085-R. We acknowledge the funding and the inputs from the other partners, who were Nauro Campos, Marek Gora, Martina Lubyova, and Jan van Ours. We also thank Randy Filer, Gerard Roland, Stepan Jurajda, Fabrizio Zilibotti, and seminar participants at CERGE-EI, ZEI-CEPR Workshop on Labor Markets in Riga, WDI-CEPR Conference on Transition Economics in Portoroz, European Economic Association Congress in Lausanne, and European Association of Labor Economists Conference in Jyvaskyla for helpful comments. 


\title{
ASSESSING THE PROBLEM OF HUMAN CAPITAL MISMATCH IN TRANSITION ECONOMIES
}

\begin{abstract}
In transition economies, there may be a significant mismatch between the types of skills that workers possess and the types of skills that the new economy demands. We consider this problem of human capital mismatch along the dimensions of training type (holding the level) and occupation. We document that in the Czech Republic and Poland the wage rate grew faster in business occupations than in technical occupations in the 1990's, and that in response the technical training/occupations contracted while the business training/occupations expanded. We do not find this pattern in Hungary. We construct a neoclassical model with endogenous occupational choice and calibrate it to the Czech and Polish data. We estimate that the discounted sum of output loss due to human capital mismatch amounts to $44 \%$ of the aggregate output of the beginning year of transition.
\end{abstract}

JEL classification: J31; J62; P23; E13

Key words: human capital; mismatch; occupation; training 


\section{William Davidson Institute Working Paper 467}

\section{Introduction}

It is commonly held that sine the level of human capital in transition countries is quite high, human capital does not pose a problem for them. This view is largely based on the fact that the level of education is quite high in these countries. In 1990, the average number of schooling years was 10.1 for Czechoslovakia, 8.9 for Hungary, and 9.5 for Poland (Barro and Lee 1996). ${ }^{1}$ These numbers are comparable to those for the OECD countries, whose average was 9.0 .

Human capital, however, is not homogeneous: an engineer and an entrepreneur may have the same level of human capital but not the same type. Suppose that in an economy there are many workers with engineering skills but few with entrepreneurial skills, yet the economy demands many entrepreneurs and few engineers. In this situation, the relative scarcity of entrepreneurs would pose a problem. To put it more generally, this is a problem of mismatch between the composition of existing human capital and that of demanded human capital. This problem of human capital mismatch may be significant for the transition countries at least during the early period of transition. The types of human capital that the command economy of the pre-transition era demanded are different from those that the market economy of transition era demands. In this paper, we assess the quantitative significance of the problem of human capital mismatch in the Czech Republic, Poland, and Hungary along their transition paths.

It is worth emphasizing that the human capital mismatch that we study in this paper is not about the level. In Labor literature, there are studies that address the mismatch between the level of the worker's human capital and the level that the job requires, in particular, overeducation (see Alba-Ramirez 1993 for an example). In Growth literature, there are studies that highlight as a problem the mismatch between the low level of the workers' human capital and the high level that a new technology requires, that is, skillbiased technological change (see for example Acemoglu and Zilibotti 2001). In this paper

\footnotetext{
1 The average for the nine 'Former Centrally Planned Economies' was 9.98.
} 


\section{William Davidson Institute Working Paper 467}

human capital mismatch is about the type, holding the level. The basic idea is that the composition of human capital in pre-transition economies was skewed toward technical training and the adjustment toward business-related human capital is taking place during transition in response to an increased demand for business training. The adjustment is composed of a change in the distribution of new graduates across training types and the movement of some workers from technical to business occupations during the early period of transition.

There are several related studies that address changes in the training type and the cross-sectoral and cross-occupational labor mobility in transition countries. ${ }^{2}$ Sarychev (1999) studies the changes from specialized vocational training to general training during the early period of transition in East Germany. Sorm and Terrell (2000) find a significant movement of labor into the finance, trade, and tourism sectors and out of the agricultural and industrial sectors in the Czech Republic. Similarly, Sabirianova (2000) finds the expansion of service and business occupations in Russia. In this paper we document the movement from technical to business training and occupation, which we consider to be a natural adjustment given the human capital mismatch. Further, we assess the quantitative significance of human capital mismatch at the aggregate level.

Our strategy is to construct an aggregate model with endogenous occupational mobility, calibrate the model using the data, and compare the trajectories of the aggregate economy during transition with and without the human capital mismatch. In Section 2, we present the model. In Section 3, we present evidence for the movement from technical to business training and occupation in the Czech Republic and Poland. (We do not find evidence for Hungary.) In Section 4, we calibrate the model in Section 2 using the data

2 There are different views about the size of labor mobility. Boeri and Flinn (1999) found that the level of worker mobility across sectors and occupations in the Czech Republic, Hungary, Poland, and Slovakia was surprisingly lower than in Italy. In contrast, Campos and Dabusinskas (2001) found a large occupational mobility during the early period of transition in Estonia, as Sorm and Terrell (2000) did in the Czech Republic. 


\section{William Davidson Institute Working Paper 467}

in Section 3 and quantify the effects of human capital mismatch during transition in the Czech Republic and Poland. We estimate that the discounted sum of output loss due to human capital mismatch amounts to $44 \%$ of aggregate output in the beginning year of transition. In Section 5, we summarize and evaluate the results.

\section{The Model Economy}

In this section, we present the model economy. The model motivates the data analysis in Section 3, and is also used for the quantitative exercise in Section 4. We first lay out the worker's decision problem in choosing a career path. Next, we show how the labor supply is derived from the individual workers' career paths. Finally, we complete the model by showing how the wage rates are determined given the labor supply and the production function.

\subsection{The Worker's Decision Problem}

A worker receives one and only one type of training before beginning his work life. There are $S$ number of training types. Let the type of training be denoted by $s=$ $1,2, \ldots, S$. The type of training a worker receives is exogenous: he takes it as given in his decision problem. A worker's work life is $J$ number of periods. Let the period of a worker's work life be denoted by $j=1,2, \ldots, J$. There are $I$ number of occupations. Let the occupation be denoted by $i=1,2, \ldots, I$. In any period of his work life, a worker can work in any of the occupations. Let the experience in an occupation by a worker, i.e., the number of periods he spent in the occupation, be denoted by $e=1,2, \ldots, J-1$. The effective labor input of a worker depends on the training he received, the occupation in which he works, and his experience in that occupation. Let $a(s, i, e)$ denote the effective labor input by a worker who is trained for occupation $s$, works in occupation $i$, and has spent $e$ number of periods working in occupation $i$. The wage of such a worker is

$$
w_{t}(s, i, e)=\tilde{w}_{t}(i) a(s, i, e)
$$




\section{William Davidson Institute Working Paper 467}

where $\tilde{w}_{t}(i)$ is the wage rate for one unit of effective labor input in occupation $i$.

Let $g_{t}(s, j)$ denote the date $t$ occupation of a worker who has training in $s$ and is in the $j$ 'th period of his work life. The career path of a worker who is trained in occupation $s$ and enters the work force in period $t$ is then $\left\{g_{t+j-1}(s, j)\right\}_{j}$. Given $\left\{g_{t+j-1}(s, j)\right\}_{j}$, the worker's experience path $\left\{e_{t+j-1}(s, j)\right\}_{j}$ is given by

$$
e_{t+j-1}(s, j)=\sum_{k=1}^{j-1} \eta\left(g_{t+j-1}(s, j), g_{t+k-1}(s, k)\right)
$$

where $\eta$ is an indicator function: $\eta\left(i, i^{\prime}\right)$ is equal to 1 if $i=i^{\prime}$, and equal to 0 otherwise. A worker's utility is the discounted linear sum of wages over his work life: the utility of a worker who is trained in occupation $s$ and enters the work force in period $t$ is

$$
\sum_{k=1}^{J} \beta^{k-1} \tilde{w}_{t+k-1}\left(g_{t+k-1}(s, k)\right) a\left(s, g_{t+k-1}(s, k), e_{t+k-1}(s, k)\right)
$$

where the discount rate $\beta<1$. A worker's decision problem is to maximize his utility by choosing his career path, taking as given his training $s$ and wage rates $\left\{\tilde{w}_{t}(i)\right\}$. The solution to this problem may not be unique: multiple career paths may maximize the worker's utility. Let $G_{t}(s)$ denote the set of utility-maximizing career paths for a worker entering the work force in period $t$ with training $s$ :

$$
G_{t}(s)=\left\{\left\{g_{t+j}(s, j)\right\}_{j}:\left\{g_{t+j}(s, j)\right\}_{j} \text { maximizes the utility of the worker }\right\} \text {. }
$$

This completes the description of the worker's decision problem.

\subsection{The Labor Supply}

In each period, many workers enter the work force. The entering workers differ in the type of training they received. Let $m_{t}(s)$ denote the number of workers who begin work life in period $t$ with training $s$. Recall from the previous subsection, multiple career paths may maximize the utility of the worker. Thus in equilibrium workers of the same cohort 


\section{William Davidson Institute Working Paper 467}

with the same training may choose different career paths. Let $\mu\left(\left\{g_{t}(s, j)\right\}_{j}\right)$ denote the fraction of workers who choose the career $\left\{g_{t}(s, j)\right\}_{j}$ :

$$
\sum_{G_{t}(s)} \mu\left(\left\{g_{t}(s, j)\right\}_{j}\right)=1
$$

Let $n_{t}(i)$ denote the number of workers in occupation $i$ in period $t$. Given the wage rates $\left\{\tilde{w}_{t}(i)\right\}$, the labor supply $\left\{n_{t}(i)\right\}$ is determined by the distribution of career paths $\left\{\mu\left(\left\{g_{t}(s, j)\right\}_{j}\right)\right\}$ that workers choose:

$$
n_{t}(i)=\sum_{\tau=t-J+1}^{t} \sum_{s} \sum_{G_{\tau}(s)} \eta\left(i, g_{t}(s, \tau+J-1)\right) \mu\left(\left\{g_{\tau}(s, j)\right\}_{j}\right) m_{\tau}(s) .
$$

The workers working in an occupation in a period will differ in terms of their effective labor input due to differences in their training and experience. Let $\tilde{n}_{t}(i)$ denote the total effective labor input in occupation $i$ in period $t$ :

$$
\tilde{n}_{t}(i)=\sum_{\tau=t-J+1}^{t} \sum_{s} \sum_{G_{\tau}(s)} \eta\left(i, g_{t}(s, \tau+J-1)\right) a\left(s, i, e_{t}\left(s, \tau_{J}-1\right)\right) \mu\left(\left\{g_{\tau}(s, j)\right\}_{j}\right) m_{\tau}(s)
$$

where the experience path $\left.e_{t}\left(s, \tau_{J}-1\right)\right)$ is determined by $(2)$ given the career path $\left\{g_{\tau}(s, j)\right\}_{j}$. Again, the labor supply $\left\{n_{t}(i)\right\}$ and the effective labor supply $\left\{\tilde{n}_{t}(i)\right\}$ may not be unique since the utility-maximizing career path of workers of the same cohort and with the same training may not be unique.

\subsection{The Aggregate Economy}

The aggregate economy is neoclassical except for the following two features. First, the labor input is differentiated by the occupation. Second, we abstract from capital accumulation and the firm's profit-maximization problem. We simply assume that there is an aggregate production function and tha wage rates are determined by the marginal products of the labor inputs. The aggregate production function is

$$
Y_{t}=A_{t} F_{t}\left(\tilde{n}_{t}(1), \tilde{n}_{t}(2), \ldots, \tilde{n}_{t}(I)\right)
$$




\section{William Davidson Institute Working Paper 467}

The wage rates are given by

$$
\tilde{w}_{t}(i)=A_{t} \cdot \frac{\partial F_{t}\left(\tilde{n}_{t}(1), \tilde{n}_{t}(2), \ldots, \tilde{n}_{t}(I)\right)}{\partial \tilde{n}_{t}(i)} .
$$

The equilibrium of the economy is the distribution of career paths $\left\{\mu\left(\left\{g_{t}(s, j)\right\}_{j}\right)\right\}$, the labor supply $\left\{n_{t}(i)\right\}$, the effective labor supply $\left\{\tilde{n}_{t}(i)\right\}$, and the wage rates $\left\{\tilde{w}_{t}(i)\right\}$ such that the distribution of career paths is derived from the workers' utility maximization problem given the wage rates; the labor supply and the effective labor supply are derived from the distribution of career paths; and the wage rates are derived from the effective labor supply.

\section{Data Analysis}

In this section, we analyze training and occupational data from the Czech Republic, Hungary, and Poland for the past decade of the transition period. The objective is to describe the evolution of labor allocation across occupations and training types during the early transition period. We will use the basic results of the data analysis for the quantitative exercise in Section 4.

Tables 1 to 3 describe the evolution of the distribution of new graduates across training types in the 1990's for the Czech Republic, Poland, and Hungary. The data come from the Statistical Yearbooks for 1994 and 1998 in the Czech Republic, ${ }^{3}$ and the Statistical Yearbooks for 1992 and 1997 in Poland and Hungary. The training is classified into eight types: business/economics, technical/engineering, agriculture, arts/humanities/social sciences, health/sports, law, natural science, and teaching. The details of constructing these tables are in the appendix. The tables show large changes in the distribution of new graduates across training types. In particular, from 1994 to 1998 in the Czech Republic the number of new graduates with technical/engineering training declined from $50.4 \%$ to

\footnotetext{
3 The Czech Republic was formed from Czechoslovakia in 1993. For consistency of data over years, we chose to use data after 1993.
} 


\section{William Davidson Institute Working Paper 467}

42.6\%. At the same time, the number of new graduates with business/economics training increased from $25.3 \%$ to $38.2 \%$. There was thus a large shift from the technical to business training. We can find this shift in Poland also: from 1992 to 1997, the number of new graduates with technical/engineering training declined from $56.1 \%$ to $45.8 \%$ whereas the number of graduates with business/economics training increased from $16.6 \%$ to 29.7\%. In Hungary, from 1992 t0 1997, there was also a decline of graduates with technical/engineering training, from $55.6 \%$ to $48.8 \%$. However, the major increase is in the arts/humanities/social science, from $2.7 \%$ to $6.1 \%$. The number of new graduates with business/economics training in fact declined slightly. Also, the overall change in distribution of new graduates is smaller in Hungary than in the Czech Republic and Poland. This probably reflects that Hungary began its transition to a market economy in the 80's, earlier than did the Czech Republic and Poland, and hence less to change in Hungary in the 90's.

Tables 4 to 6 describe the evolution of the distribution of workers across occupations in the 1990's for the Czech Republic, Poland and Hungary. The data come from the Microcensus conducted in 1992 and 1996 in the Czech Republic, the Labor Force Surveys conducted in February 1995 and February 1999 in Poland, and the Wage and Earnings Surveys conducted in 1995 and 1998 in Hungary. ${ }^{4}$ In the Czech Republic and Poland, occupations are classified into 27 two-digit ISCO-88 occupations; in Hungary, they are classified into 39 two-digit HSCO-93 occupations, which are similar to ISCO-88. The occupations are ordered by the growth rate of the number of workers. In the Czech Republic

\footnotetext{
4 In the Czech Republic there were no other years in which the Microcensus was conducted. (The Czech Labor Force Surveys do not include wage data, to which we will turn shortly.) The Microcensus for 1992 was conducted for Czechoslovakia, from which the Czech Republic was formed in 1993. However, we used data that were extracted only for the Czech Republic. We were forced to use the 1992 Microcensus despite its inconsistency with the 1996 Microcensus in this respect. In Poland the Labor Force Surveys were conducted quarterly since May 1992, but there was a change in the occupational classification system to ISCO-88 in May 1994 and further, information about wages was absent until February 1995. In Hungary the Wage and Earnings Survey was also conducted in 1992, but there was a change in the occupational classification system to HSCO-93 in 1995. For consistency of data over time, we chose not to use these earlier surveys for Poland and Hungary.
} 


\section{William Davidson Institute Working Paper 467}

from 1992 to 1996 business-related occupations tended to expand while the technical occupations tended to contract. To be more precise, consider ISCO-88 occupations 12, 13, 41, 42, 52, and 91, which are basically managers, salespersons, clerks, and office workers, as business-related occupations. The number of workers in these occupations as a share of all workers increased from $18.7 \%$ to $24.0 \%$. Now consider ISCO-88 occupations $21,31,32,33$, $34,71,72,73,74,81,82,83$, and 93 which are technicians, machine operators, mechanics, etc., as technical occupations. The number of workers in these occupations declined from $62.5 \%$ to $59.2 \%$. This movement from technical occupations to business occupations is similar to the changes in the distribution of new graduates across training types described above. Further, the average wage rate of the business occupations grew $4 \%$ more than the average wage rate of all workers. In contrast, that of the technical occupations grew $8 \%$ less than the average wage rate of all workers. This wage growth differential between the business and the technical occupations suggests that the labor movement was driven by changes in demand: the new economy demanded larger business occupations and smaller technical occupations.

In Poland from 1995 to 1999, we can observe a similar, albeit weaker, pattern. The business occupations grew from $26.1 \%$ to $27.1 \%$ while the technical occupations declined from $60.0 \%$ to $55.9 \%$. Again, this is similar to the changes in the distribution of training types in the 1990's in Poland. The wage growth rate of business occupations is $5 \%$ greater than the wage growth rate of all workers, and the wage growth rate of technical occupations is $5 \%$ less than the wage growth rate of all workers, indicating that the demand change was the source of the labor movement.

In Hungary, the labor movement across occupations was different from those of the Czech Republic and Poland. Consider HSCO-93 occupations 21, 31, 52, 71, 72, 73, 74, 75, 76, 81, 82, and 83 as technical occupations. From 1995 to 1998, this group of occupations grew from $58.1 \%$ to $61.9 \%$. This change is not only the opposite of that found for the Czech Republic and Poland, but also of the changes in the Hungarian distribution of 


\section{William Davidson Institute Working Paper 467}

new graduates mentioned above. A further surprise is that the wage rate of technical occupations grew $2 \%$ more than the average wage of all workers, indicating a positive demand change for technical occupations. Now consider HSCO-93 occupations 13, 14, 25, 36, 39, 41, 42, 51, and 91 as business occupations. Again, contrary to the pattern for the Czech Republic and Poland, the business occupations as a group declined from 29.3\% to $24.5 \%$. At the same time, the wage rate of business occupations grew $5 \%$ more than the average wage of all workers. These findings for Hungary seem hard to understand intuitively. But, given that Hungary began its transition to a market economy earlier than the other two countries, perhaps it is not so surprising that we do not find a simple pattern of labor movement that would indicate a major change of the labor market conditions.

In summary, the educational and occupational data show that there was a major shift of labor from technical training/occupations to business training/occupations in the 1990's in the Czech Republic and Poland. This seems consistent with the impression one obtains from casual observation of transition economies: the pre-transition economy was skewed toward technical training/occupations and the transition involves the expansion of occupations that require business training. For Hungary, the data do not show an intuitively clear pattern of labor movement across training/occupations. In particular, the overall data do not show a shift from technical to business training/occupations that is observed for the Czech Republic and Hungary.

\section{Quantitative Exercise}

In this section, we adapt the model in Section 2 to the transition environment based on the results from Section 3 to assess the quantitative importance of human capital mismatch in transition economies. Recall that the labor reallocation in the Czech Republic and Poland is characterized by that from the technical to business training/occupations, but the labor reallocation in Hungary was difficult to characterize. Thus we conduct

the exercise based on the data for the Czech Republic and Poland. However, under the 


\section{William Davidson Institute Working Paper 467}

assumption that the Hungarian transition of the 1980's was similar to that of the Czech Republic and Poland in the 1990's, the results may also be relevant to the early period of transition in Hungary.

The transition is modeled as follows. The economy is assumed to be on a balanced growth path for $t \leq 0$. There is an unexpected change in the production function starting period $t=1$ so that the demand structure (i.e., relative demand for occupations) changes. The change is gradual, but much of it occurs in the early periods of transition. The labor allocation across occupations changes following the change in demand structure. This change in labor allocation has two parts. First, the distribution of new workers across training types adjusts exogenously over time to match the changing demand structure. Again, much of the change in training occurs in the early periods of transition. Second, for some periods workers, old and new, may choose to work in occupations for which they are not trained.

For the exercise, we need to specify the number of types of training $S$, the number of occupations $I$, the number of periods of work life $J$, the individual effective labor input function $a(s, i, e)$, the discount rate $\beta$, the distribution of new workers over training types $\left\{m_{t}(s)\right\}$, the sequence of aggregate productivity $\left\{A_{t}\right\}$, the production function for $t \leq 0$ denoted by $F_{o}$, and the production function for $t \geq 1$ denoted by $F_{n}$. We set $S=2$ and $I=2$. Training type/occupation 1 is meant to be a business-related one, and training type/occupation 2 a technical one. We set $J=10$. This implies that the length of a period is 4 years under the assumption that a worker's work life is 40 years. We set $\beta=.85$. This implies the real annual interest rate of about $4 \%$ under constant consumption over periods. We assume the effective labor function to take the form

$$
\begin{array}{ll}
\log a(s, i, e)=\sigma_{1} e-\sigma_{2} e^{2} & \text { for } s=i \text { and } \\
a(s, i, e)=\lambda a(s, s, e) & \text { for } s \neq i,
\end{array}
$$

where $\sigma_{1}, \sigma_{2}>0$ and $0<\lambda<1$. The first equation is Mincerian, as commonly used in the Labor literature (see for example Mincer). It captures the increasing and concave wage 


\section{William Davidson Institute Working Paper 467}

profile over experience. We set $\sigma_{1}=.10$ and $\sigma_{2}=.05$. The parameter $\lambda$ captures the effective labor input of a worker who works in an occupation that he is not trained for. The calibration for this parameter will be discussed later.

We set the production functions to be

$$
F_{t}\left(\tilde{n}_{t}(1), \tilde{n}_{t}(2)\right)=\left[\tilde{n}_{t}(1)^{\alpha_{0}} \tilde{n}_{t}(2)^{1-\alpha_{0}}\right]^{2 / 3}
$$

for $t \leq 0$,

$$
F_{t}\left(\tilde{n}_{t}(1), \tilde{n}_{t}(2)\right)=\left[\tilde{n}_{t}(1)^{\alpha_{t}} \tilde{n}_{t}(2)^{1-\alpha_{t}}\right]^{2 / 3}
$$

for $t \geq 1$, and

$$
\frac{\alpha_{t+1}-\alpha_{t}}{\alpha_{\infty}-\alpha_{t}}=\rho
$$

where $0<\alpha_{0}, \alpha_{\infty}<1$ and $0<\rho<1$. The parameter $\alpha_{0}$ captures the relative demand for the two occupations before transition. The relative demand changes during transition: $\alpha_{t}$ is increasing in $t$. The parameter $\alpha_{\infty}$ captures the relative demand in the long run and the parameter $\rho$ captures the speed of change in demand, a higher value meaning a faster change. The calibration of $\alpha_{0}, \alpha_{\infty}$, and $\rho$ will be discussed later. We assume the sequence of productivity $\left\{A_{t}\right\}$ to have followed some constant annual growth path for $t \leq 0$. This pre-transition growth rate of productivity is not essential for the exercise and does not need to be specified. We assume the sequence of productivity to follow a new constant annual growth path after the transition starts: for $t \geq 1$

$$
A_{t+1}=A_{t}^{1+\gamma}
$$

We set $\gamma=.082$, which implies an annual growth rate of about $2 \%$. This growth rate does not seem to be an unreasonable estimate for transition economies at least in the medium run.

We assume no population growth and normalize the number of workers who enter the work force to be one: $m_{t}(1)+m_{t}(2)=1$. Thus at any date there are 10 people in the work 


\section{William Davidson Institute Working Paper 467}

force, each person representing a different age group. As for the distribution of workers across training types, we set $m_{0}(1)=\alpha_{0}$ for all $t \leq 0$, and

$$
\frac{m_{t+1}(1)-m_{t}(1)}{\alpha_{\infty}-m_{t}(1)}=\sigma
$$

for $t \geq 1$. This specification insures that before transition the composition of new workers each period exactly met the old demand structure, and will exactly meet the new demand structure in the long run. The parameter $\sigma$ captures the speed of change in the distribution of new workers across training types. Since the change in the distribution of new workers can only marginally change the distribution of all workers, the change in the distribution of all workers over training types will in general lag behind the change in the relative demand of occupations.

The parameters that remain to be chosen are $\lambda$ that captures the effective labor input of a worker with a training-occupation mismatch, $\alpha_{0}$ that captures both the pretransition relative demand for occupations and the pre-transition distribution of workers over training types, $\alpha_{\infty}$ that captures the demand and distribution in the long run, $\rho$ that captures the speed of change in the demand for occupations, and $\sigma$ that captures the speed of change in the distribution of new workers across training types. To choose values for these parameters, we use the results from the data analysis in Section 3. Table 7 summarizes the labor reallocation from the business to the technical training/occupations in the Czech Republic and Poland. To illustrate how the table was constructed, in 1992 in Poland the number of new graduates with business training was 86,209 and the number of new graduates with either business or technical training was 291,451. For the purpose of calibration, we ignore the graduates with neither business nor technical training, and define the share of business training to be the ratio of these two numbers, or $22.8 \%$. The share of business occupations is calculated in a similar way. In 1992 in the Czech Republic the share of business occupations was $23.0 \%$. Looking at these numbers, we could guess that the business share of training/occupation may have been around $20 \%$ in 1990 , the 


\section{William Davidson Institute Working Paper 467}

beginning year of transition. Thus we set $\alpha_{0}$ to be .20 . To calibrate the parameter $\alpha_{\infty}$, we need to make a guess about the business share of training/occupation in the long run. For this purpose, we calculated the business share of training in 1993 for Austria in the same way as we did for the Czech Republic, Poland, and Hungary. ${ }^{5}$ We found that the business share of training was $57.3 \%$ in Austria. Austria is in many ways a good benchmark for assessing the economic future of the Czech Republic and, to a lesser extent, of Poland. Based on this, we set $\alpha_{\infty}$ to be .60 . To calibrate $\sigma$, note that the business share of training reached 39.4\% in 1997 in Poland and 47.2\% in 1998 in the Czech Republic. The year 1998 corresponds to the end of date 2 in the model. From these numbers, we take as a condition that the business share of training reach $45 \%$ at date 2 , i.e., $m_{2}(1)=.45$. Given that $\alpha_{0}=.20$ and $\alpha_{\infty}=.60$, we can calculate that $\sigma=.39$ using equation 15 .

Now the only free parameters are $\lambda$ and $\rho$. These parameters are difficult to relate to the data directly. Instead we choose the values of these two parameters so that the endogenous variables under the chosen values match the data along some dimensions. The algorithm for finding the equilibrium under a given set of parameter values is as follows. First, we set the labor supply for $t \geq 1$ to be such that every worker works in the occupation for which he is trained, i.e., workers with business training work in the business occupation and workers with technical training work in the technical occupation. Second, we calculate the wage rates for $t \geq 1$ under this labor supply. Third, we solve the careerdecision problems of individual workers under these wage rates and derive a new labor supply for $t \geq 1$. Fourth, we update the original labor supply by a small amount so that it is closer to the new labor supply. This marginal update rule avoids the non-converging oscillation of labor supply as the update is repeated. Fifth, we recalculate the wage rates for $t \geq 1$ under this updated labor supply. Sixth, we repeat the third, the fourth, and the

\footnotetext{
5 The data come from the Austrian Statistical Yearbook 1993 and the Austrian Statistics on Universities: Study Year 1992/93.
} 


\section{William Davidson Institute Working Paper 467}

fifth steps until the labor supply and the wage rates converge. By construction, the limit of the convergence is the equilibrium.

The features of data that we want the model to replicate are the size of labor reallocation across occupations and the wage differential between occupations. As for the labor reallocation, note from Table 7 that the business share of occupation was $28.8 \%$ in 1996 in the Czech Republic and 32.6\% in 1999 in Poland. From this we take as a condition that in the model the business share of occupations be $31 \%$ at date 2 , an $11 \%$ increase from date 0 . As for the wage differential, note from Tables 4 and 5 that the wage of business occupations grew faster than that of technical occupations by $12 \%$ in the Czech Republic from 1992 to 1996, and by 10\% in Poland from 1995 to 1999. From this we take as a condition that in the model the wage differential at date 2 be $25 \%$, that is, the ratio of the average wage of the business occupation and the average wage of the technical occupation be 1.25 , a change from 1.00 at date 0 . We calculated equilibria using various values of $\lambda$ and $\rho$, and found the pattern that for a higher $\lambda$ or for a higher $\rho$, there is more labor reallocation. Intuitively, for a higher $\lambda$ the efficiency loss of labor input from moving from the business to the technical occupation is lower, and this would make people more willing to move; for a higher $\rho$, the change in the composition of demand for the business vs. the technical occupation is slower, and this would create less of a wage premium for the business occupation, consequently attracting a lower number of movers. Thus each value of $\lambda$ is mapped to a unique value of $\rho$ so that under the two values the business share of occupations is $31 \%$ at date 2 . We also found that as we increase $\lambda$, at the same time decreasing $\rho$ according to the mapping, the wage differential decreases. In fact, we can deduce this pattern as a property of the model: given the Cobb-Douglas production function, a lower $\rho$ implies a lower business share of aggregate wage bill, and under a fixed business share of occupations this leads to a lower average wage of the business occupation relative to that of the technical occupation. Thus there is a unique set of values of $\lambda$ and 


\section{William Davidson Institute Working Paper 467}

$\rho$ under which the business share of occupations is $31 \%$ and the wage differential is $25 \%$ at date 2 . These values are $\lambda=.76$ and $\rho=.23$.

Table 8 and Figures 1 to 3 describe the equilibrium for the calibrated economy. During the early transition, the differential in the effective wage between the business occupation and the technical occupation increases, reaching $63 \%$ at one point. The labor allocation shifts from the technical to business occupation. This is because first, the share of new workers with business training increases and second, some workers with technical training choose to work in the business occupation. Workers who choose to work in the business occupation despite technical training are $6.4 \%$ of all workers at date 1 . At date 2 , there are some additional workers who choose to work in the business occupation despite technical training, making the total $7.1 \%$. For these workers, the benefit of wage premium in the business occupation outweighs the loss of individual effective labor input due to improper training and to lack of experience. ${ }^{6}$ Although they enjoy the wage premium in business occupations, their wage is lower than that of their fellow workers with business training and experience. This lowers the average wage rate in the business occupation (i.e., the total wage bill divided by the number of workers in the business occupation). Hence the average wage differential between the business and the technical occupations is less than the effective wage differential between the two occupations. At its height, the average wage differential reaches only $40 \%$.

During transition, there is a rapid drop of output followed by a gradual increase. ${ }^{7}$ The dotted line in Figure 1 is the hypothetical output path under the assumption that

\footnotetext{
6 These workers are all from the youngest age group in the labor force. Younger workers have less experience and thus their loss of effective labor input from working in the business occupation is lower. Further, young workers have more remaining work life to accumulate experience in the business occupation. On the other hand, since the wage premium of the business occupation is temporary, the older workers can take advantage of this premium by moving into the business occupation for a greater fraction of the remaining work life than younger workers. Under the set of values chosen for the exercise, the experience factor outweighs the temporary-premium factor. This result is consistent with the empirical findings in Sorm and Terrell (2000).

7 We do not attach a significant meaning to the output drop. This is an artifact of the assumed production function and the assumed parameter-shifting over time, hardly an explanation for the observed output drop during early transition.
} 


\section{William Davidson Institute Working Paper 467}

there were no problems of human capital mismatch, that is, under the assumption that in each period and for each age group, the composition of workers across business vs. technical training were (magically) the same as the composition of demand across business vs. technical occupations. There is an initial drop of output in the hypothetical output path as in the actual output path. The actual output is lower than the hypothetical output precisely due to the human capital mismatch: the composition of workers over training lags behind the changing composition of demand. The actual output path gradually catches up with the hypothetical output path as the composition of workers over training catches up with the composition of demand and the workers who work in the business occupation despite their technical training retire. The one-period loss of output due to human capital mismatch is in the order of a few percents. We can calculate the sum of the output loss over the periods, discounted to date 0 . This amounts to $11 \%$ of date 0 output. Since the length of a period is assumed to be 4 years, this is equivalent to $44 \%$ of the output in the beginning year of transition.

\section{Conclusion}

In this paper, we assessed the problem of human capital mismatch in Central European countries during transition to the market economy. For the Czech Republic and Poland, we could characterize the human capital mismatch as the skewed distribution of existing human capital toward the technical type in contrast to the high demand for the business type. This is supported by the evidence that technical training/occupations contracted and business training/occupations expanded in the 1990's, and that the wage rate grew faster in business occupations than in technical occupations. For Hungary, we could not discern an obvious problem of human capital mismatch in the 1990's. This may be because Hungary started the transition to a market economy earlier than did the Czech Republic and Poland, and much of the labor market change took place before the 1990's. Based on a model calibrated to the data of the Czech Republic and Poland, we estimated that 


\section{William Davidson Institute Working Paper 467}

the discounted sum of output loss due to human capital mismatch amount to $44 \%$ of the aggregate output in the beginning year of transition. In other words, Czechs and Poles would have been willing to pay $44 \%$ of the 1990 GDP in exchange for eliminating the human capital mismatch problem. This is not a small sum. Lucas (1987) estimates the welfare effect of business cycles in the US to be equivalent to perpetually losing about one half percentage of consumption, which translates to less than $15 \%$ of the current year's GDP. In other words, Americans would be willing to pay less than $15 \%$ percent of any given year's GDP in exchange for eliminating business cycles forever. In these terms, our results suggest that the problem of human capital mismatch in the Czech Republic and Poland (and perhaps in transition economies in general, by extension) is quantitatively significant.

We are aware of possible objections to our results. Perhaps most significantly, we took the changing demand structure as given: the Czech and Polish economies must be restructured so that the composition of human capital becomes similar to that of Austria in the long run. Our analysis of the data suggests that empirically this is not a bad approximation. Still, the initial composition of human capital could affect the long-run demand structure for various reasons, and the long-run demand structure in the Czech Republic and especially Poland may turn out to be more technically oriented than we assumed, given that their initial composition of human capital was technically skewed. We leave this issue of the endogenous evolution of demand structure to future research. We also leave the issue of optimal policy regarding the human capital mismatch problem for further research. However, we can say that the educational system has adjusted significantly in response to the changing demand structure in the Czech Republic and Poland, as evidenced by the dramatic changes in the composition of graduates across training types. We don't see any obvious policy shortcomings, but nor do we have the final words on this. 


\section{William Davidson Institute Working Paper 467}

Appendix

Tables 1, 2, and 3 were constructed by pooling various training types from the Statistical Yearbooks of the Czech Republic, Poland, and Hungary into several broad training types that are common to the three countries. We used the following definitions of training types.

Czech Republic. Secondary: business/economics = entrepreneurship in industries in vocational education; technical/engineering = machine control and operation + mechanical engineering and metallurgy + electrical engineering, transport and communications + chemistry, food industry + construction + fashion and clothing + textile and garment industry + wood processing, shoe industry; agriculture $=$ agriculture and forestry + veterinary medicine; arts, humanities, social sciences $=$ arts and handicraft + librarians and journalists + arts + philosophy and theology; health/sports $=$ health services + physical culture, training and sports; law = public and legal administration; natural science = environmental protection; teaching $=$ pedagogy; grammar = grammar schools. University: business/economics = economics; technical/engineering $=$ mining + metallurgy + mechanical engineering + electrical engineering + industrial chemistry + food + architecture + construction + footwear industry + wood and paper production + transport; agriculture = agriculture, forestry and veterinary medicine; arts, humanities, social sciences $=$ philosophy + politics + history + journalism + philology + psychology + sciences of arts; health/sports $=$ medicine and pharmacy + physical culture; law = law; natural sciences $=$ physics and mathematics + geology + geography + chemistry + biology + ecology and environmental protection; teaching $=$ pedagogy + teacher training.

Poland. Secondary: business/economics = commercial and business + services; technical/engineering $=$ trade, craft and industrial programs + transport and communications; agriculture = agriculture, forestry and fishery; arts, humanities, social sciences $=$ fine and applied arts; health/sports = health-related auxiliaries; teaching = teacher training; grammar = grammar schools. University: business $/$ economics $=$ commercial and business administration + services; technical/engineering $=$ engineering + architecture and town planning + transport and communications; agriculture = agriculture, forestry and fishery; arts, humanities, social sciences $=$ fine and applied arts + humanities + religion and theology + social and behavioral science + home economics + mass communication and documentation; health/sports = medical science; law = law; natural sciences = natural science + mathematics and computer science; teaching = education science and teacher training. 


\section{William Davidson Institute Working Paper 467}

Hungary. Secondary: business/economics $=$ economic + commercial + trade + catering + miscellaneous and servicing industries; technical/engineering $=$ mining + metallurgy + engineering + other iron and metal industry + electrical engineering and energy industry + precision engineering + chemical industry + paper industry + food processing industry + building material industry + construction + transport, post, telecommunications + textile industry + leather, fur and shoe industry + clothing industry + wood industry + printing industry; agriculture = plant cultivation + animal husbandry; arts, humanities, social sciences = art; health/sports = sanitary; teaching = kindergarten teachers; grammar = grammar schools. University: business/economics = economics; technical/engineering $=$ engineering; agriculture = agricultural + veterinary; arts, humanities, social sciences $=$ liberal arts + fine arts + theology; health, sports $=$ medical science + sanitary + physical education; law = law and state administration; natural sciences = natural science; teaching = teacher training (higher grade) + teacher training (higher grade) for disabled children + teacher training (lower grade) + kindergarten teacher. 


\section{William Davidson Institute Working Paper 467}

\section{References}

Acemoglu, D. and Zilibotti, F. (2001), "Productivity Differences," Quarterly Journal of Economics 116:563-606.

Alba-Ramirez, A. (1993), "Mismatch in the Spanish Labor Market: Overeducation?," Journal of Human Resources 28(2):259-78.

Austrian Central Statistical Office (1993), Austrian Statistical Yearbook 1993, Austria.

Austrian Central Statistical Office (1993), Austrian Statistics on Universities: Study Year 1992/93, Austria.

Barro, R. and Lee, J. (1996), "International Measures of Schooling Years and Schooling Quality," American Economic Review 86:218-23.

Boeri, T. and Flinn, C. (1999), "Returns to Mobility in the Transition to a Market Economy," Journal of Comparative Economics 27:4-32.

Campos, N. and Dabusinskas, A. (2001), "So Many Rocket Scientists, So Few Marketing Clerks: Determinants and Impact of Occupational Change during the Estonian Transition," Manuscript, Department of Economics, University of Newcastle.

Czech Statistical Office (1994), Statistical Yearbook of the Czech Republic 1994, Czech Republic.

Czech Statistical Office (1998), Statistical Yearbook of the Czech Republic 1998, Czech Republic

Czech Statistical Office, Czech Microcensus 1992 (data set), Czech Republic.

Czech Statistical Office, Czech Microcensus 1996 (data set), Czech Republic.

Hungarian Central Statistical Office (1993), Statistical Yearbook of Hungary 1992, Hungary.

Hungarian Central Statistical Office (1998), Statistical Yearbook of Hungary 1997, Hungary.

Hungarian National Labor Center, Wage and Earnings Surveys 1995 (data set), Hungary.

Hungarian National Labor Center, Wage and Earnings Surveys 1998 (data set), Hungary.

Mincer, J. (1974), Schooling, Experience, and Earnings, National Bureau of Economic Research, United States. (Reprint in 1993 by Gregg Revivals, England.)

Polish Central Statistical Office (1994), Statistical Yearbook of the Republic of Poland 1994, Poland.

Polish Central Statistical Office (1998), Statistical Yearbook of the Republic of Poland 1998, Poland.

Polish Central Statistical Office, Labor Force Surveys: May 1995 (data set), Poland.

Polish Central Statistical Office, Labor Force Surveys: May 1999 (data set), Poland. 
Sabirianova, K. (2000), "The Great Human Capital Reallocation: An Empirical Analysis of Occupational Mobility in Transitional Russia," Working Paper 309, William Davision Institute, University of Michigan.

Sarychev, A. (1999), "Dynamic Skills Acquisition Choice - Jacks of All Trades vs. Dab Hands," Manuscript, Economics Department, Massachusetts Institute of Technology.

Sorm, V. and Terrell, K. (2000), "Sectoral Restructuring and Labor Mobility: A Comparative Look at the Czech Republic," Journal of Comparative Economics 28:431-55. 


\section{William Davidson Institute Working Paper 467}

Table 1. Educational Change in the Czech Republic from 1994 to 1998

\begin{tabular}{l|rr}
\hline Education Type & 1994 Graduates & 1998 Graduates \\
\hline Secondary Total & $151,156(1.000)$ & $159,441(1.000)$ \\
business/economics & $34,077(.225)$ & $55,517(.348)$ \\
technical/engineering & $67,423(.446)$ & $63,528(.398)$ \\
agriculture & $8,973(.059)$ & $7,872(.049)$ \\
arts/humanities/social science & $1,772(.012)$ & $2,178(.014)$ \\
health/sports & $8,601(.057)$ & $5,275(.033)$ \\
law & $3,721(.025)$ & $822(.005)$ \\
natural science & $0(.000)$ & $141(.001)$ \\
teaching & $1,948(.013)$ & $1,129(.007)$ \\
grammar & $24,640(.163)$ & $22,979(.144)$ \\
\hline University Total & $18,509(1.000)$ & $25,960(1.000)$ \\
business/economics & $2,536(.137)$ & $6,443(.248)$ \\
technical/engineering & $5,709(.308)$ & $5,729(.221)$ \\
agriculture & $1,447(.078)$ & $1,416(.055)$ \\
arts/humanities/social science & $1,245(.067)$ & $2,842(.110)$ \\
health/sports & $1,904(.103)$ & $1,979(.076)$ \\
law & $698(.038)$ & $1,150(.044)$ \\
natural science & $969(.052)$ & $1,464(.056)$ \\
teaching & $4,001(.216)$ & $4,937(.190)$ \\
\hline Secondary and University Total & $145,025(1.000)$ & $162,422(1.000)$ \\
business/economics & $36,613(.253)$ & $61,960(.382)$ \\
technical/engineering & $73,132(.504)$ & $69,257(.426)$ \\
agriculture & $10,420(.072)$ & $9,288(.057)$ \\
arts/humanities/social science & $3,017(.021)$ & $5,020(.031)$ \\
health/sports & $10,505(.072)$ & $7,254(.045)$ \\
law & $4,419(.031)$ & $1,972(.012)$ \\
natural science & $969(.007)$ & $1,605(.010)$ \\
teaching & $5,949(.041)$ & $6,066(.037)$ \\
\hline
\end{tabular}

Note: Secondary and Universtiy Total excludes grammar 


\section{William Davidson Institute Working Paper 467}

Table 2. Educational Change in Poland from 1992 to 1997

\begin{tabular}{l|rr}
\hline Education Type & 1992 Graduates & 1997 Graduates \\
\hline Secondary Total & $522,029(1.000)$ & $536,394(1.000)$ \\
business/economics & $64,689(.124)$ & $104,212(.194)$ \\
technical/engineering & $276,727(.530)$ & $245,276(.457)$ \\
agriculture & $36,389(.070)$ & $29,354(.055)$ \\
arts/humanities/social science & $20,130(.039)$ & $3,204(.006)$ \\
health/sports & $10,775(.021)$ & $2,841(.005)$ \\
law & $0(.000)$ & $0(.000)$ \\
natural science & $0(.000)$ & $0(.000)$ \\
teaching & $2,519(.005)$ & $7(.000)$ \\
grammar & $110,800(.212)$ & $151,500(.282)$ \\
\hline University Total & $107,941(1.000)$ & $216,809(1.000)$ \\
business/economics & $21,520(.199)$ & $74,683(.345)$ \\
technical/engineering & $14,724(.136)$ & $30,238(.140)$ \\
agriculture & $4,309(.040)$ & $4,840(.022)$ \\
arts/humanities/social science & $21,093(.195)$ & $2,842(.110)$ \\
health/sports & $1,904(.103)$ & $15,675(.072)$ \\
law & $3,594(.033)$ & $5,320(.025)$ \\
natural science & $5,587(.052)$ & $5,725(.026)$ \\
teaching & $18,966(.176)$ & $43,708(.202)$ \\
\hline Secondary and University Total & $519,170(1.000)$ & $601,703(1.000)$ \\
business/economics & $86,209(.166)$ & $178,895(.297)$ \\
technical/engineering & $291,451(.561)$ & $275,514(.458)$ \\
agriculture & $40,698(.078)$ & $34,194(.057)$ \\
arts/humanities/social science & $41,223(.079)$ & $39,824(.066)$ \\
health/sports & $28,923(.056)$ & $18,516(.031)$ \\
law & $3,594(.007)$ & $5,320(.009)$ \\
natural science & $5,587(.011)$ & $5,725(.010)$ \\
teaching & $21,485(.041)$ & $43,715(.073)$ \\
\hline & &
\end{tabular}

Note: Secondary and Universtiy Total excludes grammar 


\section{William Davidson Institute Working Paper 467}

Table 3. Educational Change in Hungary from 1992 to 1997

\begin{tabular}{l|rr}
\hline Education Type & 1992 Graduates & 1997 Graduates \\
\hline Secondary Total & $133,911(1.000)$ & $132,222(1.000)$ \\
business/economics & $27,661(.207)$ & $29,916(.226)$ \\
technical/engineering & $65,767(.491)$ & $54,728(.414)$ \\
agriculture & $6,041(.045)$ & $5,947(.045)$ \\
arts/humanities/social science & $564(.004)$ & $1,623(.012)$ \\
health/sports & $3,440(.026)$ & $3,310(.025)$ \\
law & $0(.000)$ & $0(.000)$ \\
natural science & $0(.000)$ & $0(.000)$ \\
teaching & $1,173(.009)$ & $271(.002)$ \\
grammar & $29,265(.219)$ & $36,427(.276)$ \\
\hline University Total & $22,384(1.000)$ & $48,582(1.000)$ \\
business/economics & $2,599(.116)$ & $3,765(.078)$ \\
technical/engineering & $4,805(.215)$ & $15,670(.323)$ \\
agriculture & $1,349(.060)$ & $4,887(.101)$ \\
arts/humanities/social science & $2,885(.129)$ & $7,239(.149)$ \\
health/sports & $2,129(.095)$ & $2,627(.054)$ \\
law & $980(.044)$ & $1,870(.039)$ \\
natural science & $1,125(.050)$ & $1,863(.038)$ \\
teaching & $6,512(.291)$ & $10,661(.219)$ \\
\hline Secondary and University Total & $127,030(1.000)$ & $144,377(1.000)$ \\
business/economics & $30,260(.238)$ & $33,681(.233)$ \\
technical/engineering & $70,572(.556)$ & $70,398(.488)$ \\
agriculture & $7,390(.058)$ & $10,834(.075)$ \\
arts/humanities/social science & $3,449(.027)$ & $8,862(.061)$ \\
health/sports & $5,569(.044)$ & $5,937(.041)$ \\
law & $980(.008)$ & $1,870(.013)$ \\
natural science & $1,125(.009)$ & $1,863(.013)$ \\
teaching & $7,685(.061)$ & $10,932(.076)$ \\
\hline & & \\
& &
\end{tabular}

Note: Secondary and Universtiy Total excludes grammar 


\section{William Davidson Institute Working Paper 467}

Table 4. Occupational Change in the Czech Republic from 1992 to 1996

\begin{tabular}{|c|c|c|c|c|c|c|}
\hline ISCO Code/Occupation & 92 Workers & 96 Workers & Growth & 92 Wage & 96 Wage & Growth \\
\hline 52 Models and sales persons (B) & $54(.019)$ & $202(.039)$ & 2.07 & 6,879 & 12,913 & .77 \\
\hline 42 Clerks (B) & $45(.016)$ & $136(.026)$ & 1.68 & 6,396 & 16,067 & 1.03 \\
\hline 61 Agriculture-market oriented & $22(.008)$ & $60(.012)$ & 1.51 & 3,989 & 13,864 & 1.43 \\
\hline 91 Elementary sales and services (B) & $13(.004)$ & $33(.006)$ & 1.41 & 3,747 & 9,249 & 1.01 \\
\hline 83 Vehicle operators $(\mathrm{T})$ & $98(.034)$ & $248(.048)$ & 1.40 & 5,600 & 11,488 & .84 \\
\hline 74 Other craft and manufacture $(\mathrm{T})$ & $41(.014)$ & $97(.019)$ & 1.31 & 6,260 & 11,711 & .77 \\
\hline 13 Managers of small companies (B) & $159(.055)$ & $373(.072)$ & 1.30 & 9,288 & 23,345 & 1.03 \\
\hline 73 Precision jobs, leather goods manufacturing $(\mathrm{T})$ & $43(.015)$ & $99(.019)$ & 1.28 & 6,449 & 13,063 & .83 \\
\hline 24 Other professional workers & $142(.049)$ & $290(.056)$ & 1.13 & 7,348 & 20,968 & 1.17 \\
\hline 32 Middle-level technicians in agriculture and health $(\mathrm{T})$ & $103(.036)$ & $208(.040)$ & 1.12 & 5,609 & 13,709 & 1.00 \\
\hline 93 Elementary mining, industry, building, and transport $(\mathrm{T})$ & $13(.004)$ & $26(.005)$ & 1.11 & 5,639 & 11,963 & .87 \\
\hline 12 Managers of big organizations (B) & $136(.047)$ & $255(.049)$ & 1.04 & 9,294 & 28,400 & 1.26 \\
\hline 71 Miners and building industry workers $(\mathrm{T})$ & $86(.030)$ & $161(.031)$ & 1.04 & 6,850 & 12,435 & .75 \\
\hline 41 Office workers (B) & $134(.046)$ & $250(.048)$ & 1.03 & 5,527 & 13,164 & .98 \\
\hline 23 Teachers & $83(.029)$ & $145(.028)$ & .97 & 5,634 & 14,009 & 1.02 \\
\hline 34 Other technicians $(\mathrm{T})$ & $283(.098)$ & $490(.094)$ & .96 & 6,825 & 14,651 & .88 \\
\hline 72 Metal treatment and mechanics $(\mathrm{T})$ & $191(.066)$ & $326(.063)$ & .95 & 5,528 & 12,233 & .91 \\
\hline 92 Elementary agriculture & $3(.001)$ & $5(.001)$ & .92 & 4,706 & 7,995 & .70 \\
\hline 51 Guards and personal service & $123(.043)$ & $204(.039)$ & .92 & 6,252 & 13,322 & .88 \\
\hline 81 Operators in mines and plants $(\mathrm{T})$ & $37(.013)$ & $61(.012)$ & .91 & 6,711 & 12,055 & .74 \\
\hline 33 Technical school teachers $(\mathrm{T})$ & $76(.026)$ & $123(.024)$ & .90 & 5,051 & 12,106 & .99 \\
\hline 21 Professionals in mathematical and technical fields $(\mathrm{T})$ & $167(.058)$ & $253(.049)$ & .84 & 8,523 & 18,104 & .87 \\
\hline 22 Professionals in natural science and health & $82(.028)$ & $122(.023)$ & .83 & 7,032 & 18,800 & 1.10 \\
\hline 31 Middle-level technicians $(\mathrm{T})$ & $645(.223)$ & $957(.184)$ & .82 & 5,986 & 14,725 & 1.01 \\
\hline 82 Machine operators and assemblers $(\mathrm{T})$ & $25(.009)$ & $37(.007)$ & .82 & 4,697 & 12,705 & 1.11 \\
\hline 11 Politicians & $66(.023)$ & $44(.008)$ & .37 & 8,357 & 21,184 & 1.04 \\
\hline 62 Agriculture-working for own consumption & $22(.008)$ & $9(.002)$ & .23 & 6,033 & 3,617 & .25 \\
\hline All business occupations & $541(.187)$ & $1,249(.240)$ & 1.28 & 7,744 & 19,487 & 1.04 \\
\hline All technical occupations & $1,808(.625)$ & $3,086(.592)$ & .95 & 6,274 & 13,926 & .92 \\
\hline All occupations & $2,892(1.000)$ & $5,214(1.000)$ & 1.00 & 6,631 & 16,048 & 1.00 \\
\hline
\end{tabular}

Note: (B) denotes business occupations; (T) denotes technical occupations; wages are in units of Czech crowns; the data for all business and all technical occupations are calculated from pooling the workers in the respective group of occupations. 


\section{William Davidson Institute Working Paper 467}

Table 5. Occupational Change in Poland from 1995 to 1999

\begin{tabular}{|c|c|c|c|c|c|c|}
\hline ISCO Code/Occupation & 92 Workers & 96 Workers & Growth & 92 Wage & 96 Wage & Growth \\
\hline 11 Politicians & $2(.000)$ & $6(.001)$ & 3.56 & 715 & 2,767 & 1.92 \\
\hline 52 Models and sales persons (B) & $200(.038)$ & $265(.060)$ & 1.57 & 284 & 597 & 1.04 \\
\hline 23 Teachers & $279(.054)$ & $330(.075)$ & 1.40 & 369 & 812 & 1.09 \\
\hline 73 Precision jobs, leather goods manufacturing $(\mathrm{T})$ & $31(.006)$ & $35(.008)$ & 1.34 & 355 & 655 & .92 \\
\hline 24 Other professional workers & $128(.025)$ & $136(.031)$ & 1.26 & 517 & 1,347 & 1.29 \\
\hline 32 Middle-level technicians in agriculture and health $(\mathrm{T})$ & $166(.032)$ & $174(.040)$ & 1.24 & 312 & 685 & 1.09 \\
\hline 33 Technical school teachers $(\mathrm{T})$ & $17(.003)$ & $17(.004)$ & 1.19 & 414 & 809 & .97 \\
\hline 93 Elementary mining, industry, building, and transport $(\mathrm{T})$ & $162(.031)$ & $160(.037)$ & 1.17 & 358 & 687 & .95 \\
\hline 31 Middle-level technicians ( $\mathrm{T}$ ) & $238(.046)$ & $232(.053)$ & 1.16 & 504 & 887 & .88 \\
\hline 21 Professionals in mathematical and technical fields $(\mathrm{T})$ & $81(.016)$ & $78(.018)$ & 1.14 & 663 & 1,332 & 1.00 \\
\hline 51 Guards and personal service & $185(.036)$ & $177(.040)$ & 1.14 & 306 & 667 & 1.08 \\
\hline 82 Machine operators and assemblers $(\mathrm{T})$ & $117(.023)$ & $110(.025)$ & 1.12 & 388 & 751 & .96 \\
\hline 34 Other technicians $(\mathrm{T})$ & $281(.054)$ & $262(.060)$ & 1.11 & 431 & 939 & 1.08 \\
\hline 83 Vehicle operators $(\mathrm{T})$ & $346(.067)$ & $310(.071)$ & 1.06 & 423 & 826 & .97 \\
\hline 22 Professionals in natural science and health & $63(.012)$ & $55(.013)$ & 1.04 & 498 & 982 & .98 \\
\hline 41 Office workers (B) & $424(.082)$ & $369(.084)$ & 1.03 & 367 & 785 & 1.06 \\
\hline 91 Elementary sales and services (B) & $362(.070)$ & $284(.065)$ & .93 & 274 & 570 & 1.03 \\
\hline 42 Clerks (B) & $111(.021)$ & $84(.019)$ & .90 & 349 & 751 & 1.07 \\
\hline 74 Other craft and manufacture $(\mathrm{T})$ & $363(.070)$ & $267(.061)$ & .87 & 321 & 651 & 1.01 \\
\hline 12 Managers of big organizations (B) & $170(.033)$ & $122(.028)$ & .85 & 608 & 1,573 & 1.28 \\
\hline 92 Elementary agriculture & $13(.003)$ & $9(.002)$ & .82 & 386 & 671 & .86 \\
\hline 13 Managers of small companies (B) & $92(.018)$ & $62(.014)$ & .80 & 636 & 1,225 & .96 \\
\hline 81 Operators in mines and plants $(\mathrm{T})$ & $142(.027)$ & $94(.021)$ & .79 & 457 & 882 & .96 \\
\hline 72 Metal treatment and mechanics $(\mathrm{T})$ & $687(.132)$ & $446(.102)$ & .77 & 436 & 842 & .96 \\
\hline 61 Agriculture-market oriented & $52(.010)$ & $33(.008)$ & .75 & 328 & 627 & .95 \\
\hline 71 Miners and building industry workers $(\mathrm{T})$ & $491(.094)$ & $268(.061)$ & .65 & 505 & 839 & .83 \\
\hline All business occupations & $1,359(.261)$ & $1,186(.271)$ & 1.04 & 377 & 793 & 1.05 \\
\hline All technical occupations & $3,122(.600)$ & $2,453(.559)$ & .93 & 430 & 822 & .95 \\
\hline All occupations & $5,203(1.000)$ & $4,385(1.000)$ & 1.00 & 411 & 827 & 1.00 \\
\hline
\end{tabular}

Note: (B) denotes business occupations; (T) denotes technical occupations; wages are in units of Polish zloty; the data for all business and all technical occupations are calculated from pooling the workers in the respective group of occupations. 


\section{William Davidson Institute Working Paper 467}

Table 6. Occupational Change in Hungary from 1995 to 1998

\begin{tabular}{|c|c|c|c|c|c|c|}
\hline HSCO Code/Occupation & 92 Workers & 96 Workers & Growth & 92 Wage & 96 Wage & Growth \\
\hline 23 Labor service professionals & $114(.000)$ & $210(.000)$ & 2.08 & 49,742 & 72,410 & .84 \\
\hline 64 Plant and soil protection & $245(.000)$ & $329(.000)$ & 1.51 & 27,664 & 39,713 & .83 \\
\hline 81 Manufacturing machine operators $(\mathrm{T})$ & $39,579(.038)$ & $50,981(.055)$ & 1.45 & 41,102 & 72,004 & 1.01 \\
\hline 62 Skilled forest and farming workers & $2,945(.003)$ & $3,699(.004)$ & 1.41 & 25,763 & 36,036 & .81 \\
\hline 53 Non-material service & $30,492(.029)$ & $33,477(.036)$ & 1.23 & 30,484 & 48,937 & .92 \\
\hline 33 Labor service occupations & $1,194(.001)$ & $1,304(.001)$ & 1.23 & 39,981 & 61,824 & .89 \\
\hline 12 Senior officials of organizations & $3,757(.004)$ & $4,023(.004)$ & 1.20 & 100,882 & 176,281 & 1.01 \\
\hline 75 Industry and warehouse workers $(\mathrm{T})$ & $18,534(.018)$ & $19,745(.021)$ & 1.20 & 34,088 & 60,995 & 1.03 \\
\hline 39 Clerks N.E.C. (B) & $7,046(.007)$ & $7,495(.008)$ & 1.19 & 47,730 & 75,454 & .91 \\
\hline 52 Transport and communication workers $(\mathrm{T})$ & $25,430(.025)$ & $26,795(.029)$ & 1.18 & 35,603 & 60,248 & .97 \\
\hline 72 Food processing and trades workers $(\mathrm{T})$ & $16,780(.016)$ & $17,663(.019)$ & 1.18 & 33,623 & 53,293 & .91 \\
\hline 25 Business, legal and social professionals (B) & $9,305(.009)$ & $9,792(.011)$ & 1.18 & 79,372 & 165,023 & 1.20 \\
\hline 51 Trade, hotel, restaurant workers (B) & $23,141(.022)$ & $22,651(.025)$ & 1.10 & 28,648 & 47,745 & .96 \\
\hline 74 Steel and metal trade workers $(\mathrm{T})$ & $171,223(.166)$ & $166,992(.181)$ & 1.10 & 36,486 & 65,484 & 1.03 \\
\hline 32 Health associate professionals & $5,523(.005)$ & $5,358(.006)$ & 1.09 & 31,970 & 53,678 & .97 \\
\hline 82 Other stationary-plant operators $(\mathrm{T})$ & $29,933(.029)$ & $28,950(.031)$ & 1.09 & 39,156 & 67,969 & 1.00 \\
\hline 24 Teaching professionals & $28,728(.028)$ & $27,579(.030)$ & 1.08 & 43,827 & 72,426 & .95 \\
\hline 92 Agricultural laborers & $2,754(.003)$ & $2,569(.003)$ & 1.05 & 21,542 & 34,330 & .92 \\
\hline 11 Senior officials of special-interest organizations & $858(.001)$ & $800(.001)$ & 1.05 & 117,769 & 263,258 & 1.29 \\
\hline 83 Mobile-plant operators $(\mathrm{T})$ & $110,129(.107)$ & $101,141(.110)$ & 1.03 & 35,855 & 60,195 & .97 \\
\hline 34 Teaching associate professionals & $4,268(.004)$ & $3,913(.004)$ & 1.03 & 31,145 & 48,776 & .90 \\
\hline 61 Skilled agricultural workers & $23,812(.023)$ & $21,792(.024)$ & 1.03 & 27,037 & 45,757 & .97 \\
\hline 73 Light industry workers $(\mathrm{T})$ & $24,787(.024)$ & $22,644(.025)$ & 1.03 & 31,277 & 49,553 & .91 \\
\hline 91 Elementary services occupations (B) & $78,796(.076)$ & $70,196(.076)$ & 1.00 & 25,778 & 42,220 & .94 \\
\hline 29 Professionals N.E.C. & $5,496(.005)$ & $4,771(.005)$ & .98 & 72,696 & 143,685 & 1.14 \\
\hline 42 Management (consumer services) clerks (B) & $3,425(.003)$ & $2,960(.003)$ & .97 & 37,271 & 70,516 & 1.09 \\
\hline 26 Cultural, sport, and artistic professionals & $3,348(.003)$ & $2,869(.003)$ & .96 & 56,366 & 80,828 & .83 \\
\hline 22 Health professionals & $9,719(.009)$ & $8,294(.009)$ & .96 & 55,507 & 90,337 & .94 \\
\hline 21 Engineering, natural science professionals $(\mathrm{T})$ & $30,838(.030)$ & $25,603(.028)$ & .93 & 63,796 & 133,632 & 1.21 \\
\hline 76 Construction workers $(\mathrm{T})$ & $77,560(.075)$ & $64,150(.070)$ & .93 & 32,952 & 55,752 & .97 \\
\hline 71 Extraction workers $(\mathrm{T})$ & $8,781(.009)$ & $7,098(.008)$ & .91 & 59,829 & 108,326 & 1.04 \\
\hline 31 Technicians, related associate professionals $(\mathrm{T})$ & $46,968(.045)$ & $37,849(.041)$ & .91 & 49,158 & 96,126 & 1.13 \\
\hline 36 Business, financial intermediation clerks (B) & $37,362(.036)$ & $29,330(.032)$ & .88 & 45,194 & 89,684 & 1.14 \\
\hline 41 Office clerks (B) & $4,107(.004)$ & $3,151(.003)$ & .86 & 38,131 & 66,691 & 1.01 \\
\hline 37 Cultural, sport, and artistic associate professionals & $3,393(.003)$ & $2,385(.003)$ & .79 & 45,135 & 65,983 & .84 \\
\hline 63 Skilled fishery workers & $559(.001)$ & $346(.000)$ & .70 & 26,232 & 39,635 & .87 \\
\hline 14 General managers (B) & $7,423(.007)$ & $4,513(.005)$ & .68 & 65,719 & 115,323 & 1.01 \\
\hline 35 Protection service associate professionals & $3,109(.003)$ & $1,869(.002)$ & .68 & 46,448 & 81,722 & 1.01 \\
\hline 13 Managers of business institutions (B) & $132,594(.128)$ & $75,240(.082)$ & .64 & 80,385 & 173,260 & 1.24 \\
\hline All business occupations & $303,199(.293)$ & $225,328(.245)$ & .83 & 55,770 & 101,330 & 1.05 \\
\hline All technical occupations & $600,542(.581)$ & $569,610(.619)$ & 1.07 & 38,680 & 68,379 & 1.02 \\
\hline All occupations & $1,034,055(1.000)$ & $920,525(1.000)$ & 1.00 & 43,880 & 76,189 & 1.00 \\
\hline
\end{tabular}

Note: (B) denotes business occupations; (T) denotes technical occupations; N.E.C in occupation titles denotes Newly Established Category; wages are in units of Hungarian forint; the data for all business and all technical occupations are calculated from pooling the workers in the respective group of occupations. 


\section{William Davidson Institute Working Paper 467}

Table 7. Business Share of Training and Occupation in the Czech Republic and Poland in the 1990's

\begin{tabular}{|c|c|c|c|c|c|c|c|c|c|c|}
\hline Data sets & 1990 & 1991 & 1992 & 1993 & 1994 & 1995 & 1996 & 1997 & 1998 & 1999 \\
\hline Training, Czech Republic (Table 1) & & & & & $33.4 \%$ & & & & $47.2 \%$ & \\
\hline Training, Poland (Table 2) & & & $22.8 \%$ & & & & & $39.4 \%$ & & \\
\hline Occupation, Czech Republic (Table 4) & & & $23.0 \%$ & & & & $28.8 \%$ & & & \\
\hline Occupation, Poland (Table 5) & & & & & & $30.3 \%$ & & & & $32.6 \%$ \\
\hline
\end{tabular}

Note: The business share of training is the number of workers with business training divided by the number of workers with business or technical training; the business share of occupations is the number of workers in business occupations divided by the number of workers in business or technical occupations. 


\section{William Davidson Institute Working Paper 467}

Table 8. Properties of the Calibrated Model

\begin{tabular}{l|rrrrr}
\hline$t$ & $Y_{t} / Y_{t}$ & $\tilde{m}_{t}(1)$ & $n_{t}(1)$ & $\tilde{w}_{t}(1) / \tilde{w}_{t}(2)$ & $w a_{t}(1) / w a_{t}(2)$ \\
\hline 0 & 1.00 & 2.00 & 2.00 & 1.00 & 1.00 \\
1 & .99 & 2.16 & 2.80 & 1.23 & 1.05 \\
2 & .98 & 2.41 & 3.11 & 1.48 & 1.25 \\
3 & .97 & 2.71 & 3.42 & 1.61 & 1.37 \\
4 & .97 & 3.06 & 3.76 & 1.63 & 1.40 \\
5 & .97 & 3.42 & 4.13 & 1.57 & 1.37 \\
6 & .98 & 3.80 & 4.51 & 1.46 & 1.30 \\
7 & .98 & 4.19 & 4.89 & 1.32 & 1.20 \\
8 & .99 & 4.58 & 5.29 & 1.17 & 1.09 \\
9 & .99 & 4.98 & 5.68 & 1.02 & .97 \\
10 & .99 & 5.37 & 6.08 & .87 & .86 \\
11 & 1.00 & 5.62 & 5.68 & 1.06 & 1.04 \\
12 & 1.00 & 5.76 & 5.76 & 1.04 & 1.02 \\
13 & 1.00 & 5.86 & 5.86 & 1.01 & 1.00 \\
14 & 1.00 & 5.91 & 5.91 & 1.00 & .99 \\
15 & 1.00 & 5.95 & 5.95 & .99 & .99 \\
16 & 1.00 & 5.97 & 5.97 & .99 & .99 \\
17 & 1.00 & 5.98 & 5.98 & .99 & .99 \\
18 & 1.00 & 5.99 & 5.99 & .99 & .99 \\
19 & 1.00 & 5.99 & 5.99 & .99 & .99 \\
20 & 1.00 & 6.00 & 6.00 & .99 & .99 \\
21 & 1.00 & 6.00 & 6.00 & .99 & .99 \\
22 & 1.00 & 6.00 & 6.00 & 1.00 & 1.00 \\
23 & 1.00 & 6.00 & 6.00 & 1.00 & 1.00 \\
24 & 1.00 & 6.00 & 6.00 & 1.00 & 1.00 \\
25 & 1.00 & 6.00 & 6.00 & 1.00 & 1.00 \\
\hline & & & & &
\end{tabular}

Note: $Y_{t} / \bar{Y}_{t}$ : output as a percentage of no-mismatch output; $\tilde{m}_{t}(1)$ : number of workers with business training; $n_{t}(1)$ : number of workers in the business occupation; $\tilde{w}_{t}(1) / \tilde{w}_{t}(2)$ : ratio of the effective wage rates (i.e., wages of one unit of effective labor) in business and technical occupations; $w a_{t}(1) / w a_{t}(2)$ : ratio of the average wage rates (i.e., the total wage bill divided by the number of workers) in business and technical occupations. 
William Davidson Institute Working Paper 467

Figure 1: Output Path of the Calibrated Model

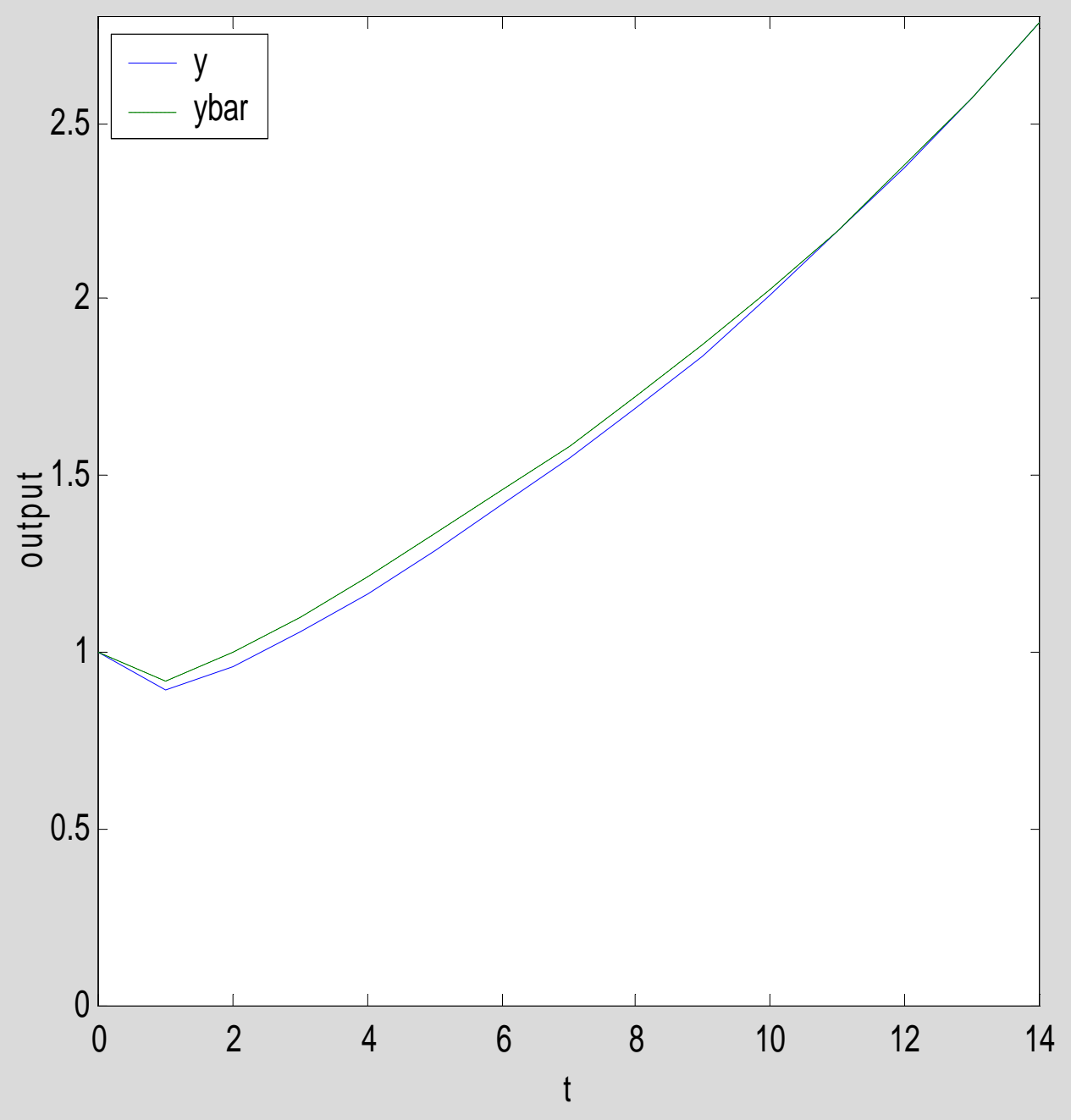


William Davidson Institute Working Paper 467

Figure 2: Occupational Distribution of Workers in the Calibrated Model

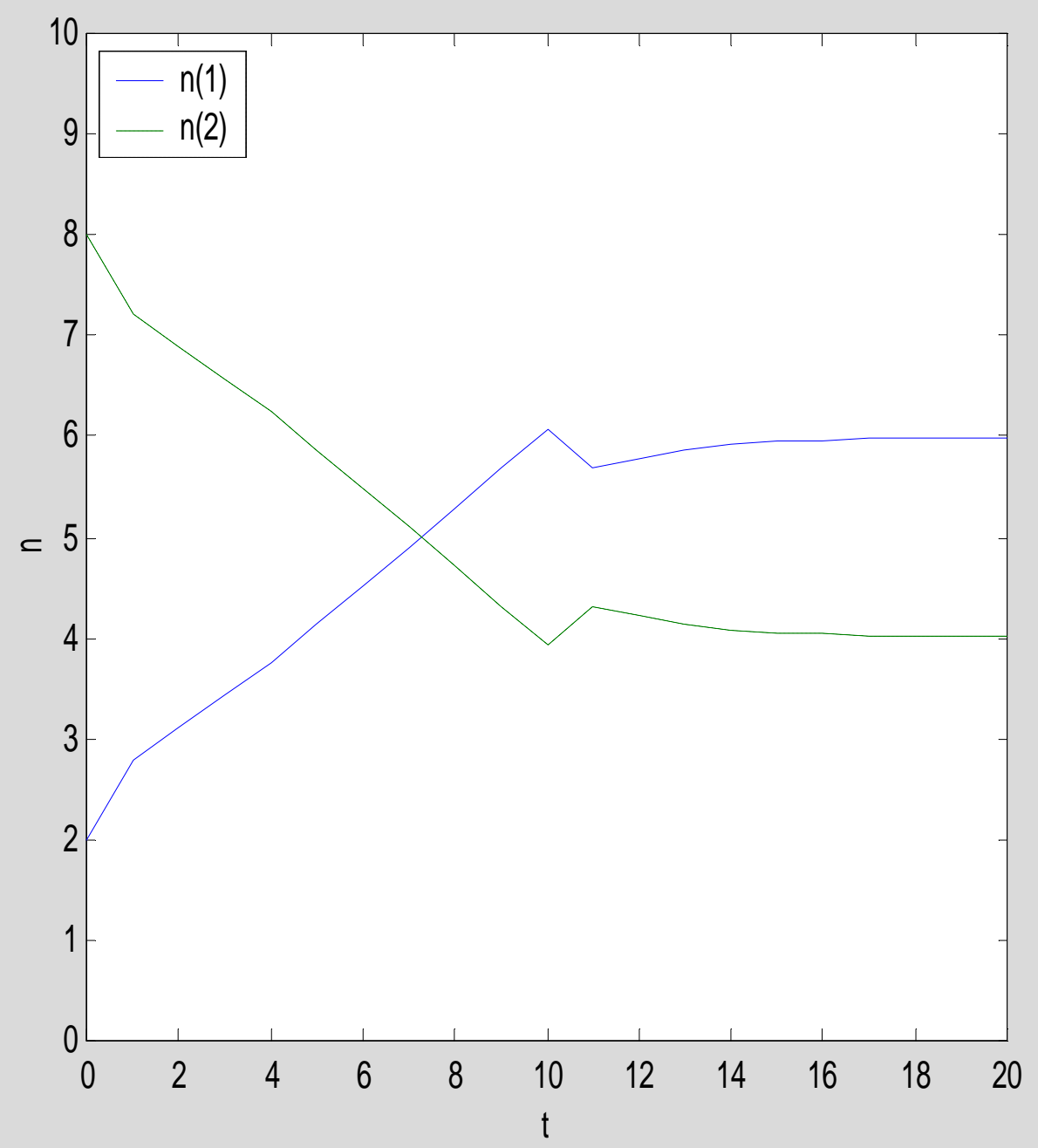


William Davidson Institute Working Paper 467

Figure 3: Average Wage Rates in the Calibrated Model

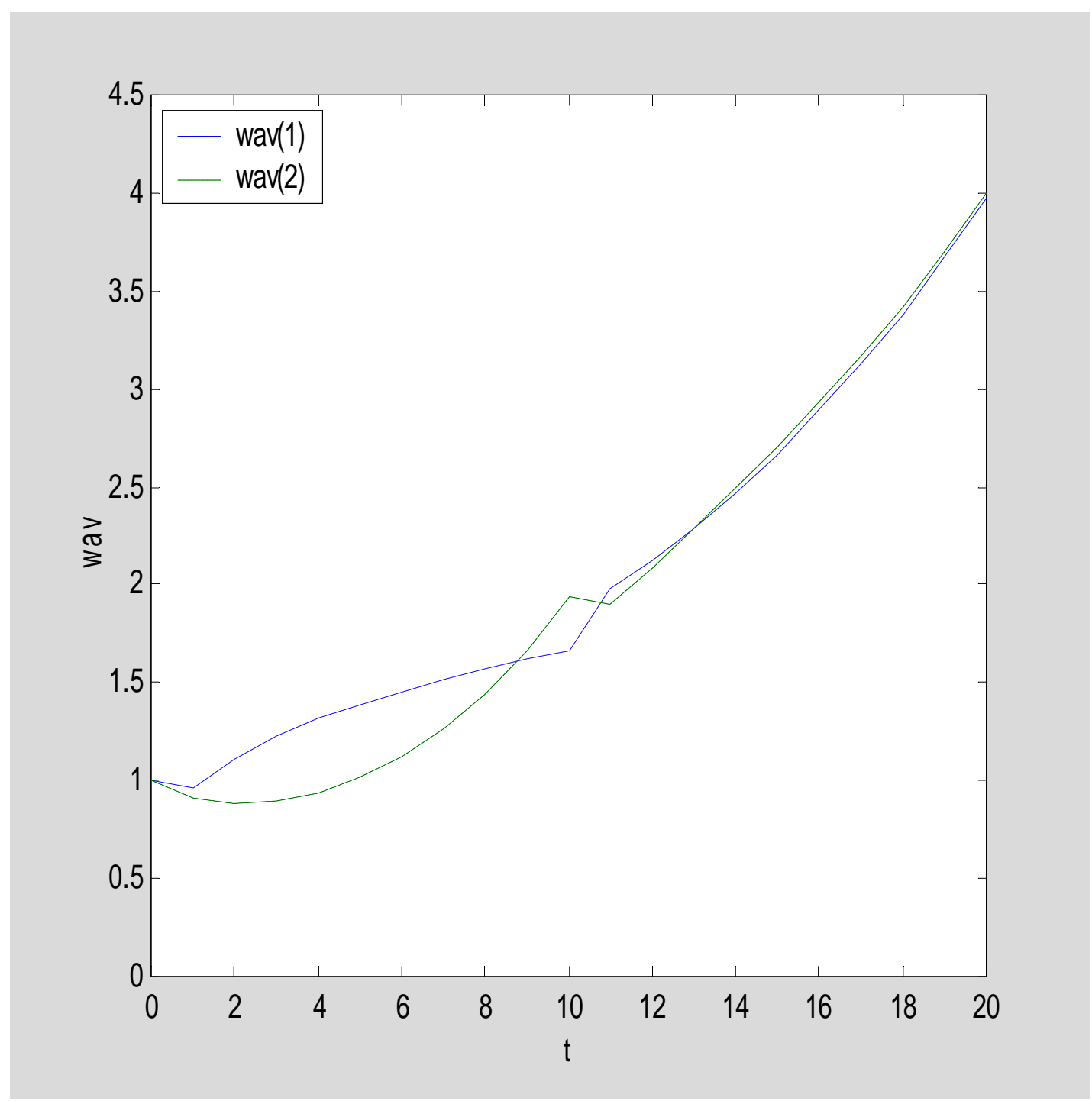




\section{DAVIDSON INSTITUTE WORKING PAPER SERIES - Most Recent Papers}

The entire Working Paper Series may be downloaded free of charge at: www.wdi.bus.umich.edu

CURRENT AS 5/9/02

\begin{tabular}{|c|c|c|}
\hline Publication & Authors & Date \\
\hline $\begin{array}{l}\text { No. 467: Assessing the Problem of Human Capital Mismatch in } \\
\text { Transition Economies }\end{array}$ & $\begin{array}{l}\text { Viliam Druska, Byeong ju Jeong, } \\
\text { Michal Kejak, and Viatcheslav } \\
\text { Vinogradov }\end{array}$ & Mar. 2002 \\
\hline $\begin{array}{l}\text { No. 466: Motivating Russian Workers: Analysis of Age and Gender } \\
\text { Differences }\end{array}$ & Susan J. Linz & Feb. 2002 \\
\hline No. 465: Virtual Reality: Barter and Restructuring in Russian Industry & Gary Krueger and Susan J. Linz & Apr. 2001 \\
\hline $\begin{array}{l}\text { No. 464: Lending of Last Resort, Moral Hazard and Twin Crises: } \\
\text { Lessons from the Bulgarian Financial Crisis 1996/1997 }\end{array}$ & $\begin{array}{l}\text { Michael Berlemann, Kalin } \\
\text { Hristov and Nikolay Nenovsky }\end{array}$ & May 2002 \\
\hline $\begin{array}{l}\text { No. 463: Deindustrialisation. Lessons from the Structural Outcomes of } \\
\text { Post-Communist Transition }\end{array}$ & $\begin{array}{l}\text { Tomasz Mickiewicz and Anna } \\
\text { Zalewska }\end{array}$ & Jan. 2002 \\
\hline $\begin{array}{l}\text { No. 462: Joint Liability Lending and the Rise and Fall of China's } \\
\text { Township and Village Enterprises }\end{array}$ & Albert Park and Minggao Shen & July 2001 \\
\hline $\begin{array}{l}\text { No. 461: A Refinancing Model of Decentralization with Empirical } \\
\text { Evidence from China }\end{array}$ & Albert Park and Min & Apr. 2002 \\
\hline $\begin{array}{l}\text { No. 460: The Effects of Market Liberalization on the Relative Earnings } \\
\text { of Chinese Women }\end{array}$ & $\begin{array}{l}\text { Margaret Maurer-Fazio and } \\
\text { James Hughes }\end{array}$ & Mar. 2002 \\
\hline $\begin{array}{l}\text { No. 459: The Role of Education in Determining Labor Market } \\
\text { Outcomes in Urban China's Transitional Labor Markets }\end{array}$ & Margaret Maurer-Fazio & Apr. 2002 \\
\hline $\begin{array}{l}\text { No. 458: Real and Monetary Convergence within the European Union } \\
\text { and Between the European Union and Candidate Countries: } \\
\text { A Rolling Cointegration Approach }\end{array}$ & $\begin{array}{l}\text { Josef C. Brada, Ali M. Kutan and } \\
\text { Su Zhou }\end{array}$ & Apr. 2002 \\
\hline No. 457: Credit Ratings as Coordination Mechanisms & $\begin{array}{l}\text { Arnoud W. A. Boot and Todd T. } \\
\text { Milbourn }\end{array}$ & Mar. 2002 \\
\hline $\begin{array}{l}\text { No. 456: Balkan and Mediterranean Candidates for European Union } \\
\text { Membership: The Convergence of their Monetary Policy with that of the } \\
\text { European Central Bank }\end{array}$ & Josef C. Brada and Ali M. Kutan & Apr. 2002 \\
\hline $\begin{array}{l}\text { No. 455: Russian Financial Transition: The Development of Institutions } \\
\text { and Markets for Growth }\end{array}$ & David M. Kemme & Oct. 2001 \\
\hline $\begin{array}{l}\text { No. 454: Does the Market Pay Off? Earnings Inequality and Returns to } \\
\text { Education in Urban China }\end{array}$ & Xiaogang $\mathrm{Wu}$ and $\mathrm{Yu} \mathrm{Xie}$ & Apr. 2002 \\
\hline $\begin{array}{l}\text { No. 453: Entrepreneurs' Access to Private Equity in China: } \\
\text { The Role of Social Capital }\end{array}$ & Bat Batjargal and Mannie M. Liu & Apr. 2002 \\
\hline $\begin{array}{l}\text { No. 452: The Determinants of Privatised Enterprise Performance in } \\
\text { Russia }\end{array}$ & $\begin{array}{l}\text { Alan A. Bevan, Saul Estrin, Boris } \\
\text { Kuznetsov, Mark E. Schaffer, } \\
\text { Manuela Angelucci, Julian } \\
\text { Fennema and Giovanni } \\
\text { Mangiarotti }\end{array}$ & June 2001 \\
\hline $\begin{array}{l}\text { No. 451: Determinants of Financial Distress: What Drives Bankruptcy } \\
\text { in a Transition Economy? The Czech Republic Case }\end{array}$ & Lubomír Lízal & Jan. 2002 \\
\hline No. 450: Corporate Governance and the Global Social Void & Lee A. Tavis & Oct. 2001 \\
\hline $\begin{array}{l}\text { No. 449: Financial Architecture and Economic Performance: } \\
\text { International Evidence }\end{array}$ & Solomon Tadesse & Aug. 2001 \\
\hline $\begin{array}{l}\text { No. 448: Growth Slowdown Under Central Planning: A Model of Poor } \\
\text { Incentives }\end{array}$ & Zuzana Brixiová and Aleš Bulír & Mar. 2002 \\
\hline $\begin{array}{l}\text { No. 447: Disentangling Treatment Effects of Polish Active Labor } \\
\text { Market Policies: Evidence from Matched Samples }\end{array}$ & $\begin{array}{l}\text { Jochen Kluve, Hartmut Lehmann, } \\
\text { and Christoph M. Schmidt }\end{array}$ & Jan. 2002 \\
\hline $\begin{array}{l}\text { No. 446: The Impact of Socialist Imprinting and Search for Knowledge } \\
\text { on Resource Change: An Empirical Study of Firms in Lithuania }\end{array}$ & $\begin{array}{l}\text { Aldas Kriauciunas and Prashant } \\
\text { Kale }\end{array}$ & Mar. 2002 \\
\hline $\begin{array}{l}\text { No. 445: The Costs, Wealth Effects, and Determinants of International } \\
\text { Capital Raising: Evidence from Public Yankee Bonds }\end{array}$ & $\begin{array}{l}\text { Darius P. Miller and John J. } \\
\text { Puthenpurackal }\end{array}$ & Oct. 2001 \\
\hline
\end{tabular}

